\title{
STUDIES ON AUTOSENSITIZATION DERMATITIS
}

\author{
KAZUYA YAMAMOTO \\ Department of Dermatology, School of Medicine, \\ Keio University
}

(Received for publication March 23, 1961)

Though the concept of autosensitization, thereby a person becomes sensitized in one or more of his organs to a substance produced from his own tissue proteins, has intrigued many investigators, Whitfield $(1,2,3)$ was the first to introduce this concept to the field of dermatology.

In 1921, Whitfield(1) reported two cases of generalized toxic eruptions, developed about ten days following large traumatic hematomas. A generalized papular, urticarial eruption appeared in a third patient eleven days after the acute exacerbation of dermatitis of the legs. In another one, a red-streaked, urticarial wheal developed whenever serum from a vesiculobullous eczema of the legs came in contact with intact areas of the skin. For the account of these peculiar dermatologic phenomena Whitfield applied the term "autosensitization."

Since that time there have been a number of descriptions of generalized skin reactions following various types of localized eczema. Dennie and others (4) reported in 1929 the occurrence of a generalized exfoliative dermatitis complicating local dermatitis around burned lesion treated with trinitrophenol, and expressed the idea that the generalized dermal reaction was due to a sensitization to protein picrinate. Brown ${ }^{(5)}$ described such widespread reactions as a sequel to a variety of forms of eczema. Hopkins and Burky(6), in 1944, reviewed the various "ids" and pointed out that they are autosensitization phenomena, and believed that a number of cases of eczema, particularly chronic eczema of the hands are due to a sensitization to a combination of the patient's own keratin and staphylococcal toxin. They claimed good therapeutic results in their patients by the use of desensitization with staphylococcal toxin. In 1945, Smith(7) used the title of "eczema autolytica" for the same type of generalized eruption as in Whitfield's third patient. He observed that patients with chronic eczema of the legs, who experienced exacerbation of the local lesion, developed in a week or two a generalized papulovesicular eruption. He thought that a dermolysin was responsible, which was formed at the primary lesion and might be a foreign 
protein derived from bacteria, a tissue breakdown product or a combination of the two. By utilization of the synergistic action of staphylococcal toxin and of homologous skin antigen, Hecht and others ${ }^{(8)}$ succeeded for the first time to produce specific antiskin antibodies in experimental animals. Templeton and others $^{(9)}$, in 1949 , described five cases of autosensitization to skin; one initiated by drugs and one by bacteria, the other three were idiopathic in origin. They were also able to demonstrate the formation of precipitins after three or four injections of homologous whole-skin extract in five human subjects. In 1950 and 1951, Cormia and Esplin(10,11) described that they found a water-soluble antigen in epidermal scales, but this was not confirmed by Lipschultz ${ }^{(12)}$.

Recently Haxthausen(13) found that 88 of 235 patients with varicose eczema developed a generalized vesicular eruption in certain predilection sites, described by Smith(7), Young(14), in 1958, reported a summary of sixty cases, and affirmed that exacerbation of localized lesion may precede the generalized autogenous eczema.

On the other hand in Europe, especially in Germany, the term of "Mikrobid" has been given to certain dermatosis, which shows almost same clinical picture in autosensitization dermatitis. According to the opinions of German investigators(15-17), "Mikrobid" might be considered as a result of allergic reaction due to some bacterial substances. A foreign bacterial protein or a bacterial toxin produced at the site of primary localized eruption were considered as antigenic factors, but a substance derived from tissue breakdown was also regarded as one of the factors by some investigators(18-23).

In Japan, since Yamazaki(24) introduced the concept of "disseminierte ekzematoide Mikrobide" and autosensitization dermatitis to us, many attempts were performed by many savants(25-27).

Further study on the elucidation of mechanism of autosensitization dermatitis is presented here.

\section{CLINICAL OBSERVATION}

Sixty-six patients with autosensitization dermatitis were observed at our clinic during two years (from May, 1957 to April, 1959). It was about $0.4 \%$ of the number of outpatients in same period (Table 1).

1) Age and Sex

The patients were able to find in all generation. Twenty-three of them, however, were third decade, and fourteen of sixty-six were second decade. Generally it was more common among youngadult and adult (Table 2). As Table 2, thirty-four of the patients were male in my cases. 
Table 1.

Number and Distribution of Patients

\begin{tabular}{ccc|ccc}
\hline Year & Month & $\begin{array}{c}\text { Number of } \\
\text { patients }\end{array}$ & Year & Month & $\begin{array}{c}\text { Number of } \\
\text { patients }\end{array}$ \\
\hline 1957 & 5 & 1 & 1958 & 5 & 5 \\
& 6 & 0 & & 6 & 4 \\
& 7 & 2 & & 7 & 7 \\
& 8 & 0 & & 8 & 1 \\
& 1 & 2 & & 10 & 4 \\
& 10 & 2 & & 11 & 4 \\
1958 & 11 & 3 & 1959 & 1 & 4 \\
& 12 & 4 & & 2 & 2 \\
& 1 & 5 & & 3 & 1 \\
& 3 & 4 & & 4 & 4 \\
\hline
\end{tabular}

Table 2.

Ages and Sex of Patients

\begin{tabular}{|c|c|c|}
\hline Age (Yr.) & Male & Female \\
\hline-10 & 1 & 1 \\
\hline $11-20$ & 7 & 7 \\
\hline $21-30$ & 12 & 11 \\
\hline $31-40$ & 3 & 7 \\
\hline $41-50$ & 8 & 4 \\
\hline $51-60$ & 0 & 2 \\
\hline $61-$ & 3 & 0 \\
\hline Totals & 34 & 32 \\
\hline
\end{tabular}

Strempel(28) reported high frequency in old age, Young(14) showed 47.7 years as average of the age of patients. In Japan, Ofuji(25), Anekoji(26) and Tanaka(27) also reported the distribution of their patients in age, and former two pointed out third decade as predilection age and another noted second decade.

There was almost no significant difference in number of patients between male and female, as reported before.

2) Seasonal Change in Number of Patients

Ofuji(25) reported summer and autumn as the season showed many patients. In my series, however, no seasonal change in distribution of patients was observed (Table 1).

3) Macroscopic Changes of Primary Lesion

As Table 3, 18 of 66 patients have been suffered from nummular eczema 
before developing secondary disseminated eruption. Chronic eczema and undetermined type of eczema were also found to be primary lesion. It was commonly observed at these primary lesion that they showed active changes, erythem, swelling and exsudation etc. In all cases with chronic eczema a secondary acute exacerbation was noted on the lesion. The infected ulcers due to burn, particularly on the legs, frequently became one of the initial localized eruptions (Fig. 1).

Table 3.

Type of Primary Lesion

\begin{tabular}{lc}
\hline \multicolumn{1}{c}{ Type } & Number of patients \\
\hline Nummular eczema & 18 \\
Chronic eczema & 18 \\
Eczema (undetermined type) & 16 \\
Burn & $\cdot 6$ \\
Contact dermatitis & 6 \\
Pyoderma & 2 \\
\hline
\end{tabular}

In the foreign literatures varicous eczema or nummular eczema was emphasized as primary lesion (Haxthausen(13), Young(14)). Because of bacterial pathogenesis of nummular eczema, and of high frequency as initial eruption, we might consider some relation between bacteria and autosensitization dermatitis.

4) Localization of Primary Lesion

Majority of the patients showed one primary lesion, but some of them, especially the case due to nummular eczema, had two or more primary lesions. 85 primary eruptions were found from 66 cases, and 45 of 85 eruptions $(52.9 \%)$ were noted on lower legs (Table 4). In many foreign and Japanese literaturs,

Table 4.

Localization of Primary Lesion

\begin{tabular}{lc}
\hline Area involved & Number of patients* \\
\hline Neck & 4 \\
Upper arm & 5 \\
Forearm \& hand & 23 \\
Trunk & 5 \\
Thigh & 3 \\
Leg \& foot & 45 \\
\hline * Patient with more than 2 primary lesions was counted \\
by the number of lesions.
\end{tabular}

lower legs were also reported as the predilection site of primary lesion(9, 25-28). These primary eruptions varied in their diameter from $2 \mathrm{~cm}$ to almost a half length of leg.

5) Localization of Secondary Disseminated Eruption 
The secondary generalized eruptions were usually observed as symmetrically disseminated lesion all over the body. In my cases, however, such disseminated lesion was noted in one third of them, and then the extremities also showed frequently to be predilection site for secondary eruption (Table 5).

Table 5.

Localization of Secondary Eruption

\begin{tabular}{lc}
\hline \hline \multicolumn{1}{c}{ Area involved } & Number of patients* \\
\hline Whole body & 22 \\
Face \& neck & 24 \\
Upper extremities & 41 \\
Lower extremities & 31 \\
Trunk & 18 \\
\hline
\end{tabular}

* Patient, had more than 2 areas involved, was counted by the number of areas.

6) Macroscopic Findings of Secondary Disseminated Eruption

The secondary eruption usually showed a multiform and changing picture. At the onset of secondary dissemination the appearance of lesion was pruritic, generalized or disseminated, miliary, erythematous, somewhat papular eruptions, and then rapidly changed to vesicles or small pustules on erythematous base (Fig. 2). As autosensitization dermatitis progressed, these disseminated eruptions tended to show variously sized patches which were raised and crusted. Individual patches were often indistinguishable from nummular eczema (Fig. 3). Frequently these eruptions were observed on intact skin as a result of mechanical irritation. Resolution of the disease was noted by dring and scaling, usually followed by pigmentation.

In two of my cases several, scaly, erythematous, oval patches like pityriasis rosea were found on their faces. Such erythematous patchy eruptions were also reported by Monacelli(29), Röckl(20) and Haxthausen(13) as one of the types of Mikrobid.

7) Period for Sensitization (from the onset of primary lesion to the development of secondary disseminated eruption)

If we could suppose that autosensitization dermatitis would be caused by allergy due to some substances, the period, which was spent for the development of secondary eruptions, might be considered as the period for forming antibody.

In my series, the period varied from two weeks to more than one year. The majority, however, was from two weeks to three months (Table 6). As shown in Table 6, there are two kinds of period, one is "after development of initial disorder" and another is "after exacerbation of primary lesion." The 
Table 6.

Period for Sensitization

\begin{tabular}{|c|c|c|}
\hline \multirow[b]{2}{*}{ Time } & \multicolumn{2}{|c|}{ Number of patients } \\
\hline & $\begin{array}{l}\text { After development } \\
\text { of initial disorder* }\end{array}$ & $\begin{array}{l}\text { After exacerbation } \\
\text { of primary lesion }\end{array}$ \\
\hline 1 week & 0 & 9 \\
\hline $2 \prime \prime$ & 7 & 11 \\
\hline 1 month & 9 & 10 \\
\hline $3 \|$ & 18 & 1 \\
\hline $6 \prime \prime$ & 15 & 0 \\
\hline 1 year & 5 & 0 \\
\hline More than 1 year & 10 & 0 \\
\hline Indistinct & 2 & 35 \\
\hline Totals & 66 & 66 \\
\hline
\end{tabular}

* The lesion, which has possibility of becomming primary lesion.

secondary dissemination of eruption was generally observed within one month after exacervation of primary lesion.

According to Sulzberger ${ }^{(30)}$, Wedroff(31) and Ofuji(25) the completion of eczematous sensitization usually required 6 to 24 days for sensitizing. These days would give us the concept of allergic origin also for this dermatosis.

8) Laboratory Examinations

Seven of 66 patients have been examined at acme of their conditions, and the results were shown in Table 7 .

Table 7.

Laboratory Examinations

\begin{tabular}{|c|c|c|c|c|c|c|}
\hline \multirow{2}{*}{ Case } & \multirow{2}{*}{ Sed. rate } & \multirow{2}{*}{ WBC } & \multicolumn{2}{|c|}{ Differential } & \multirow{2}{*}{$\begin{array}{l}\text { Liver } \\
\text { function }\end{array}$} & \multirow{2}{*}{$\begin{array}{c}\text { Thorn } \\
\text { test }\end{array}$} \\
\hline & & & Eosino. \% & Neutro. $\%$ & & \\
\hline 1 & 5.5 & 6200 & 10.0 & 54.5 & normal & 51.3 \\
\hline 2 & 2.0 & 5800 & 10.0 & 56.5 & $\|$ & \\
\hline 3 & 4.8 & 5400 & 5.0 & 42.0 & " & \\
\hline 4 & 11.5 & 6000 & 5.0 & 55.0 & $\|$ & \\
\hline 5 & 4.0 & 6300 & 3.0 & 69.0 & $\|$ & 45.0 \\
\hline 6 & 5.3 & 4500 & 5.5 & 70.0 & " & 84.0 \\
\hline 7 & 20.0 & 4700 & 6.0 & 48.0 & $\|$ & 40.5 \\
\hline
\end{tabular}

Red cell sedimentation rate, urinalysis, liver function test and Thorn test with ACTH were all within normal limits. In CBC, white blood cell count was also within normal limits, and slight increasing of eosinophils was noted in 3 of 7 cases.

Because of no evidence of leukocytosis, it could be considered that autosensitization dermatitis would not be included in simple purulent dermatosis, 
though it might have some relation to bacterial infection.

9) Glucose Tolerance Test

It is well-known fact that some of skin disorders are closely related to the disturbance of glucose metabolism. Yasuda(32) emphasized a gentle rise and fall, and a delaied restoration in glucose tolerance test of the patient with autosensitization dermatitis. Then he suggested that these changes in the test might be one of the factors to induce autoeczematization.

Same 7 patients also have had this test, which was performed by the administration of $30 \mathrm{~g}$ glucose in $200 \mathrm{cc}$ of water, and blood sugar content was measured by Hagedorn-Jensen's method. As Table 8 , the results of test were all found within the range of normal variations, except one case of hyperglycemia.

Table 8.

Glucose Tolerance Test

\begin{tabular}{ccccc}
\hline \hline & FBS & $\frac{1}{2} \mathrm{hr}$ & $1 \mathrm{hr}$ & $2 \mathrm{hr}$ \\
\hline $\begin{array}{c}\text { Normal value } \\
(\mathrm{mg} / \mathrm{dl})\end{array}$ & 101.6 & 148.9 & 144.0 & 99.2 \\
Case & & & & \\
2 & 116.5 & 152.0 & 145.0 & 120.0 \\
3 & 114.9 & 195.0 & 176.0 & 113.9 \\
4 & 108.1 & 166.2 & 114.0 & 78.0 \\
5 & 96.2 & 150.0 & 128.0 & 78.0 \\
6 & 86.0 & 118.0 & 93.9 & 90.0 \\
7 & 81.8 & 132.9 & 122.1 & 90.0 \\
\hline
\end{tabular}

\section{MICROSCOPIC FINDINGS OF SECONDARY DISSEMINATED ERUPTION}

The various stage of lesions developing during secondary dissemination were observed histologically in 6 cases.

The biopsy taken from relatively new lesion showed following changes. The epidermis was acanthotic, and covered by a slightly parakeratotic horny layer, which revealed some defect. There was moderate inter-and intracellular edema in the epidermis. The vessels in the papillae were dilated. The upper part of the dermis showed a interstitial edema and a perivascular small round cell infiltration mostly consisting of lymphocytes and few neutrophils. There was considerable migration of small round cells through the epidermis (Fig. 4).

In further advanced eruption a intraepidermally located large vesicle formation was frequently observed. Considerable intercellular edema and intracellular edema were present in the epidermis surrounding the vesicle. Migrating lymphocytes and neutrophils were present in the epidermis, and the vesicle contained few lymphocytes and neutrophils. In the upper dermis there were vascular 
dilatation, edema and perivascular small round cell infiltration (Fig. 5).

Some of the lesion showed a pustular change due to acute folliculitis and perifolliculitis. These cases presented a pustule situated in the opening and upper part of a hair follicle. A considerable inflammatory infiltrate containing many polymorphonuclear leukocytes and lymphocytes surrounded the upper portion of hair follicle. There were slight intra- and interepidermal edema in the epidermis, and perivascular small round cell infiltration in the dermis (Fig. 6).

In brief the histopathologic changes of secondary disseminated eruption generally consist of the following findings; a slight acanthosis, intra- and intercellular edema and a intraepidermal vesicle formation in the epidermis. Migrating lymphocytes and neutrophils are present in the epidermis and vesicle. A vascular dilatation, edema and a perivascular small round cell infiltration in the upper part of the dermis. The occurrence of pustule formation at the site of hair follicle. These microscopic findings are almost similar to the description by Young(14), and might be considered as an eczema-like reaction.

\section{BACTERIOLOGICAL EXAMINATION}

Rayer(33) had observed the frequent association of impetigo and eczema. Around the turn of the century many investigators, notably Unna( ${ }^{(34)}$ and Engman ${ }^{(35)}$, regarded staphylococei as the chief cause of eczema. In recent years Lane and his co-workers ${ }^{(36)}$, Storck(17), Fowle(37) and Röckl(21) have studied the bacterial flora of eczematous eruptions and have reaffirmed the etiological importance of bacteria in general and of staphylococci in particular.

1) Cutaneous Flora of Primary Eczematous Lesion and Normal Skin

The investigation of cutaneous flora was performed by "Abklatschmethode"(17) for 20 patients with autosensitization dermatitis. The cultures were taken by pressing the chocolate agar contact plate against an eczematous primary lesion and by applying another contact plate to an area symmetrical with the lesion, if it was free from the eruption.

As a result of this survey I found a wide difference in the number of colonies between the contact plates pressed on the normal skin and those of the primary lesion including 9 nummular eczema, 6 chronic eczema, 3 undetermined type of eczema and 2 burn (Fig. 7 and 8 ). The colonies from the primary lesion were almost innumerable, while those from the normal skin were usually less than fifty colonies.

The colonies showed a wide variation of bacterial species, and Staphylococcus, Streptococcus, Corynebacterium, Escherihia coli and Pseudomonas pyocyamea etc. were frequently isolated. There was found to be no significant qualitative 
difference of the flora between normal areas and eczematous lesions. However staphylococci predominated in all contact plates, and especially on the primary eczematous lesion the colonies of staphylococci took more than $90 \%$ of the number of whole colonies.

2) Differentiation and Classification of Staphylococci from Primary Lesion In a series of 20 patients, cultures were made from plaques of primary eczematous eruption on chocolate agar plate, and 34 strains of staphylococci were isolated from these plates and examined.

Differentiation of species or typing of staphylococci has centered largely around the problem of pathogenicity. The correlation between coagulase activity and virulence is very high, and the terms "virulent" and "coagulase-positive" have come to be almost interchangeable. Coagulase-positive staphylococci are almost invariably pigmented, e.g., strains of Staphylococcus aureus, usually ferment mannitol, dextrose, maltose and glycerol, and liquefy gelatin. Coagulasepositive strains are practically invariably hemolytic on blood agar.

All of 34 strains were classified by some reliable indication of probable pathogenicity; pigment formation, hemolytic activity, coagulase activity and mannitol fermentation. If the old classification by pigment formation is concerned, 27 strains $(79.4 \%)$ were Staph. aureus, 7 strains $(20.6 \%)$ were Staph. albus and there was no strain of Staph. citrens. As a result of this examination I found $21(61.2 \%)$ strains of pathogenic staphylococci, which showed pigment formation, hemolytic activity, coagulase activity and mannitol fermentation (Table 9).

Table 9.

Classification of Staphylococci from Primary Lesion

\begin{tabular}{lrrrrrrr}
\hline \hline & $\begin{array}{c}\text { Number of } \\
\text { strains }\end{array}$ & \multicolumn{2}{c}{$\begin{array}{c}\text { Hemolytic } \\
\text { activity } \\
+\end{array}$} & \multicolumn{2}{c}{$\begin{array}{c}\text { Coagulase } \\
\text { activity } \\
+\quad\end{array}$} & $\begin{array}{c}\text { Mannitol } \\
\text { fermentation } \\
+\end{array}$ \\
\hline Staph. aureus & $27 \ldots \ldots \ldots$ & 22 & 5 & 21 & 6 & 27 & 0 \\
Staph. albus & $7 \ldots \ldots \ldots$ & 4 & 3 & 1 & 6 & 1 & 6 \\
Staph. citreus & $0 \ldots \ldots \ldots$ & 0 & 0 & 0 & 0 & 0 & 0 \\
\hline
\end{tabular}

According to these findings it is granted that the pathogenic forms of staphylococci are significantly high in a primary lesion. Therefore, it would be valuable to give much attention to these organisms from the lesion.

3) Drug Resistance in Hemolytic Staphylococci from Primary Lesion

Since it is wellknown fact that the administration of antibiotics induces a good result on exsudative, infected eczematous eruption, the most significant 
hindrance from the practical point of view is the acquisition of drug resistance of staphylococci. With the general use of penicillin over a period of ten years, increasing proportions of staphylococci isolated are found to be penicillinresistant. Resistance of staphylococci to the other commonly used drugs, such as chlortetracycline and chloramphenicol, appears to be rising also and, in addition, strains of staphylococci resistant to more than one drug occur with some frequency,

For 22 strains of hemolytic, pigmented staphylococci, isolated from the various primary lesions, the drug-sensitivity to several antibiotics was determined with different concentrations of drugs. The concentrations in $\gamma / \mathrm{cc}$ and $\mathrm{u} / \mathrm{cc}$ required to inhibit the growth of those strains in vitro were shown in Table 10. In this series, staphylococci were most susceptible to erythromycin,'

Table 10.

Drug Resistance in 22 Strains of Staphylococci

\begin{tabular}{lcccc}
\hline \hline \multicolumn{1}{c}{ Name of } & \multicolumn{4}{c}{ Concentration } \\
antibiotics & 0.1 & 1 & 10 & 100 \\
\hline Penicillin & 12 & 11 & 9 & 7 \\
Streptomycin & 22 & 22 & 11 & 1 \\
Chloramphenicol & 22 & 22 & 16 & 0 \\
Oxytetracycline & 22 & 22 & 4 & 2 \\
Chlortetracycline & 22 & 22 & 7 & 3 \\
Tetracycline & 22 & 22 & 2 & 2 \\
Erythromycin & 21 & 0 & 0 & 0 \\
Leucomycin & 22 & 21 & 1 & 1 \\
\hline
\end{tabular}

Figure shows the number of strains, which continued to grow against certain concentration of antibiotics.

* Except penicillin (u/cc).

being inhibited completly by only $1 \gamma / \mathrm{cc}$ of it. Penicillin was diluted as $\mathrm{u} / \mathrm{cc}$, and 7 of 22 strains still continued to grow even in $100 \mathrm{u} / \mathrm{cc}$ of penicillin.

4) Bacteriophage Typing of Coagulase-Positive Strains of Staphylococcus aureus from Primary Lesion

The correlation between coagulase activity and virulence is very high, and coagulase-positive staphylococci are not differentiated by the usual cultural reactions. Therefore, attempts have been made to define types within this group on the basis of serological character and susceptibility to strains of bacteriophage. A routine method for the identification of strains of Staphylococcus aureus by means of bacteriophages was described by Wilson and Atkinson(38) in 1945 and has since been used in the investigation of numerous outbreaks. Unfortunately, however, the set of phages in use at present gives pattern reaction rather than truly type-specific reactions; that is, one strain may be lysed by 
several different phages, and each of these phages may enter into a number of different patterns on different strains. The bacteriophage patterns fall into four groups that can be reasonably easily defined and have been referred to in the past as the $3 \mathrm{~A}, 6 / 47,52$ and $42 \mathrm{D}$ groups.

For this paper I have classified 22 independent strains of Staph. aureus, which have been used in drug resistance test, by Ujiie and Ito's method(39) with 20 different bacteriophages of N.C.T.C. (Table 11).

Seven of 22 strains were lysed by one or more of the phages in my set, and 6 of the lysed strains were all classified into group III (Table 12).

Table 11.

Phages defining the Four Groups of Staphylococci

\begin{tabular}{rlrllllllll}
\hline \hline Group & \multicolumn{10}{c}{ Phages Characteristic of the Group } \\
\hline I & 29, & $52 \mathrm{~A}$, & 52, & 79 & & & & & \\
II & $3 \mathrm{C}$, & $3 \mathrm{~B}$, & $3 \mathrm{~A}$, & 55, & 71 & & & & \\
III & 70, & $42 \mathrm{E}$, & 6, & 7, & 73, & 47, & 54, & 75, & 53, & 77 \\
IV & $42 \mathrm{D}$ & & & & & & & & \\
\hline
\end{tabular}

Table 12.

Phage Groups of 7 Lysed Staphylococci

\begin{tabular}{|c|c|c|c|c|c|}
\hline $\begin{array}{l}\text { Number of } \\
\text { strains }\end{array}$ & 29 & $\begin{array}{c}\text { Phage an } \\
53\end{array}$ & $\begin{array}{l}\text { dissolution } \\
42 \mathrm{E}\end{array}$ & 73 & Group \\
\hline 1 & \pm & \pm & & & $0+*$ \\
\hline 18 & & & & ++ & III \\
\hline 19 & & & \pm & ++ & III \\
\hline 20 & & & \pm & ++ & III \\
\hline 21 & & & & ++ & III \\
\hline 22 & & & \pm & $+t$ & III \\
\hline 23 & & & \pm & ++ & III \\
\hline
\end{tabular}

It has been already emphasised by many investigators $(39,40)$ that there are the great predominance of group III strains among the penicillin-resistant staphylococci. In this series, these 6 typable strains were also found to have their ability of growth in $100 \mathrm{u} / \mathrm{cc}$ of penicillin.

5) Culture of Bacteria from Seconadry Disseminated Eruption and Venous Blood

In general, the contents of newly developed, secondary disseminated eruptions are considered to be sterile ${ }^{(25)}$. If autosensitization dermatitis is caused by the secondary hematogenous dissemination of cutaneous flora of a primary lesion, 
the contents may not be sterile. Four cases with secondary disseminated vesicular eruption were examined, and 3 fresh, non-crusted vesicles were selected from each patient. The contents of these vesicles were cultured by blood agar plate and blood broth, no growth of bacteria being observed.

The attempts for detecting hematogenous bacterial dissemination also made by agar plate and broth with the patient venous blood drawn at the acme of the disease. All of 6 investigated patients showed no evidence of bacteria in their venous blood.

\section{IMMUNOLOGIC EXAMINATION}

The mechanism involved in autosensitization dermatitis, as interpreted by observation of the clinical development, has a significant resemblance to that of an allergic reaction as defined by von Pirquet. In autosensitization dermatitis it is assumed that an antigenic substance is elaborated at the site of an acute primary eczematous focus. If this primary inflammatory focus persists unabated for a minimal period of seven to fourteen days, it may be postulated that the continual absorption of antigenic material is constantly stimulating the formation of antibodies. Further absorption of antigen then leads to the development of secondary eczematous lesions at distant sites. Experimental confirmation of the immunologic mechanisms involved in this concept should include the positive identification of the antigen and antibody.

One method of separating and identifying complicated mixtures of antigen and antibody is the diffusion-in-gel technique. When employing antigens, sharply defined zones of reaction are noted because precipitation occurs only in the area of optimal concentration of both antigen and antibody. In order to compare reactions between the serum of normal individuals and of patients to several antigenic substances, the complex, double-diffusion agar-gel technique of Ouchterlony ${ }^{(41)}$ was used. This method employs an agar plate and permits a two-dimensional diffusion of both antigen and antibody.

1) Materials and Methods

In this study, 13 patients were utilized, all with definite clinical evidence of widespread cutaneous autosensitization. The following test substances were used: (a) serum, (b) extract of scales, (c) filtrates of broth cultures, (d) extract of staphylococci, (e) sensitized scale extract and (f) controls. It should be emphasized at this point that each patient was tested with the products of staphylococci, which were isolated from his lesion.

Preparation of Serum:-Blood was collected in the fasting state from 13 patients with autosensitization dermatitis and two normal individuals, and 
allowed to clot at room temperature. The serum was separated by centrifugation and kept at $-20^{\circ} \mathrm{C}$, and then inactivated before using.

Preparation of Scale Extract:-A relatively hairless site of normal individual was prepared with $70 \%$ ethyl alcohol, and scales were obtained by gentle curettement with a sterile scalpel. The scales were then placed in a sterile glass vial containing an isotonic solution of sodium chloride of a volume of $10 \mathrm{cc}$ to $1 \mathrm{~g}$ of the scales, and this vial was kept at room temperature for 6 hours after adding $1 \mathrm{cc}$ of $\mathrm{N} / 10 \mathrm{NaOH}$. Then the solution was extracted by shaking at $20^{\circ} \mathrm{C}$ for 12 hours, and again kept for 24 hours at room temperature, and centrifuged at $3,000 \mathrm{rpm}$ for 20 minutes. The supernatant fluid was withdrawn, and filtered by the Seitz filter. After this step $\mathrm{M} / 5 \mathrm{KH}_{2} \mathrm{PO}_{4}$ to make a final $\mathrm{pH}$ of 7.0 was added into the filtrate.

Preparation of Sterile Filtrates of Staph. Broth Cultures:-Hemolytic, coagulase-positive, mannitol-fermentive pigmented staphylococci were isolated from the primary lesion of each patient, who had this immunologic test. Colonies were transferred to beef broth for growth, and cultured for 10 days at $37^{\circ} \mathrm{C}$. These broth cultures were filtered by the Seitz filter. Then the filtrates were heated under a certain low pressure, and concentrated to a quarter in their own volume.

Preparation of Extracts of Staphylococci:-The same staphylococci as used for preparing the filtrates were used for this preparation. Each isolated strain was cultured in beef broth for 24 hours at $37^{\circ} \mathrm{C}$, and spreaded over a big agar plate. After 24 hours at $37^{\circ} \mathrm{C}$, bacterial cells were collected from the plate by washings with normal saline. The washings were repeated three times by centrifuging at $3,000 \mathrm{rpm}$ for 30 minutes each time. Then the bacteria were suspended again in saline solution. Suspensions thus made were kept at equivalent concentrations (50 $\mathrm{mg}$ of bacteria in wet condition per cubic centimeter of normal saline) by measuring with a spectrophotometer. $20 \mathrm{cc}$ of each suspension was treated with sonic vibration for 20 minutes, and bacterial cells were destroyed. After destruction $2 \mathrm{cc}$ of $\mathrm{N} / 10 \mathrm{NaOH}$ were added to the suspension, and the extraction was carried out by shaking at relatively low temperature for 12 hours and centrifugation at $25,000 \mathrm{rpm}$ for 20 minutes by the Spinco Model L. The supernatant fluid was withdrawn, and the final $\mathrm{pH}$ of extract was adjusted to 7.0 with $\mathrm{M} / 5 \mathrm{KH}_{2} \mathrm{PO}_{4}$.

Preparation of Sensitized Scale Extracts:-Two kinds of sensitized scale extracts were made by the following method; a certain volume of scale extract and the same volume of sterile filtrate of bacterial broth culture were mixed up and kept at $37^{\circ} \mathrm{C}$ for 4 hours. Then the same procedure was performed with 
the scale extract and the extract of staphylococci.

Preparation of Controls:-Control serum was obtained as mentioned in Preparation of Serum. As control to the strains used, a standard strain, 209 P, was selected, from which each preparation as mentioned above was made. Also sterile beef broth was concentrated to a quarter in its volume as control to sterile filtrates of broth cultures.

All test substances, described above, were kept in sterile condition by the addition of $0.01 \%$ merthiolate.

Performance of Tests:-One of the modified methods of Ouchterlony's technique by Katsura ${ }^{(42)}$, or Wilson and Pringle ${ }^{(43)}$ was used for this investigation. Two per cent of agar in water was melted and cooled down to about $56^{\circ} \mathrm{C}$, and $0.01 \%$ merthiolate was added. Six $\mathrm{ml}$ of the agar suspension was then pipeted into a Petri dish (about $9 \mathrm{~cm}$ in diameter) and allowed to harden. Seven small aluminum cylinders ( $8 \mathrm{~mm}$ in diameter) were placed on the surface of the agar, one in the center and the others equidistant apart each other. Then $15 \mathrm{cc}$ of the agar suspension was again pipetted, and allowed to harden with the covers ajar to prevent accumulation of water of condensation on the surface of the agar. By removing 7 cylinders from the plate, 7 holes were excavated.

Serum and other materials were placed in each hole according to the pattern for location (Fig. 9) and combination (Table 13). The holes were refilled on the 3rd and 6th day and the plate was kept at room temperature, and read and photographed 10 days later.

2) Results of Experiments

As can be seen in the accompanying figure and table, reactions were encountered most commonly with extracts of staphylococci (both patients' own strains and $209 \mathrm{P}$ ), Six of 13 patients showed in their sera-extracts of staph. (both patients' own strains and $209 \mathrm{P}$ ) systems the most marked precipitation lines, and of these 6 patient sera-sensitized scale extracts (sensitized by extracts from both patients' own strains and $209 \mathrm{P}$ ) systems, 4 revealed weak and hazy lines (Fig. 10). Presumably the dilution of test substances due to preparation of sensitized scale extracts might cause such difference in density of the bands. One extra band was also demonstrated in the serum-extract system in one of six cases. However, no precipitate was formed by any other combination of the test substances.

A summary of the reactions is shown in Table 13. According to the results of these experiments it seemed to be confirmed that of 13 patients with autosensitization dermatitis, 6 have the antibody to the extracts of staphylococci (both their own strains and $209 \mathrm{P}$ ) in their sera. Therefore, it would be 
valuable to give much attention to the bacterial cell substances of staphylococci for detecting the cause of this dermatosis.

Table 13.

Result of Immunologic Examination

\begin{tabular}{|c|c|c|c|c|c|c|c|c|c|c|}
\hline \multirow{2}{*}{$\begin{array}{c}\begin{array}{c}\text { Serum } \\
\text { case No. }\end{array} \\
\text { (patient) }\end{array}$} & \multirow[t]{2}{*}{$\begin{array}{c}\text { (1) } \\
\text { Scale } \\
\text { ext. }\end{array}$} & \multicolumn{2}{|c|}{$\begin{array}{l}\text { (2) } \\
\text { Filtrates } \\
\text { of staph. }\end{array}$} & \multicolumn{2}{|c|}{$\begin{array}{c}\text { (3) } \\
\text { Extracts } \\
\text { of staph. }\end{array}$} & \multicolumn{2}{|c|}{$\begin{array}{c}\text { (4) } \\
\text { Scale + } \\
\text { filtrates }\end{array}$} & \multicolumn{2}{|c|}{$\begin{array}{c}(5) \\
\text { Scale + } \\
\text { extracts }\end{array}$} & \multirow[t]{2}{*}{$\begin{array}{c}(6) \\
\text { Control } \\
\text { broth }\end{array}$} \\
\hline & & own & $209 \mathrm{P}$ & own & $209 \mathrm{P}$ & own & $209 \mathrm{P}$ & own & $209 \mathrm{P}$ & \\
\hline 1 & - & - & - & - & - & - & - & - & - & - \\
\hline 2 & - & - & - & $t$ & + & - & - & \pm & \pm & - \\
\hline 3 & - & - & - & - & - & - & - & - & - & - \\
\hline 4 & - & - & - & - & - & - & - & - & - & - \\
\hline 5 & - & - & - & + & + & - & - & - & - & - \\
\hline 6 & - & - & - & + & + & - & - & \pm & \pm & - \\
\hline 7 & - & - & - & - & - & - & - & - & - & - \\
\hline 8 & - & - & - & + & + & - & - & - & - & - \\
\hline 9 & - & - & - & - & - & - & - & - & - & - \\
\hline 10 & - & - & - & + & + & - & - & \pm & \pm & - \\
\hline 11 & - & - & - & + & + & - & - & \pm & \pm & - \\
\hline 12 & - & - & - & - & - & - & - & - & - & - \\
\hline $\begin{array}{c}13 \\
\text { (normal) }\end{array}$ & - & - & - & - & - & - & - & - & - & - \\
\hline 1 & - & - & - & - & - & - & - & - & - & - \\
\hline 2 & - & - & - & - & - & - & - & - & - & - \\
\hline
\end{tabular}

\section{COMMENT}

In the studies herein reported, an attempt has been made to clarify some of the mechanisms involved in autosensitization dermatitis. The body does not normally become sensitized to its own tissues, and for this to occur the tissue must be presented to the body in an abnormal form. In the skin the abnormality may be a sequel to tissue degeneration where proteins in various stages of degeneration are present at the same instant. In the majority of cases, part of this process may be the sensitization of the body to extraneous material which may include bacteria or fungi and their toxins, or certain tissue reactive chemicals. These may form protein-hapten complexes with the tissue components, or may act as complete antigens, with the end result that antibodies with skin specificity are formed. To make a diagnosis of autosensitization it is essential to demonstrate that circulating antibodies or cellular sensitivity exists specific for the body tissues.

Hecht, Sulzberger and Weil(8) were able to demonstrate the presence of precipitating antibodies to homologous skin in rabbits by the intramuscular injection of skin with adjuvant and repeated intracutaneous injection of staphy- 
lococcal toxin. However, the antigen was obtained from pieces of skin that were not bacteriologically sterile. Simon $(44,45)$ failed to find sensitivity to certain micro-organisms including staphylococci by direct skin test or passive transfer test with patient serum. But Lipschultz(12) was of the opinion that bacteria, particularly Staphylococcus albus, were responsible for his patients.

The results obtained in the present clinical and experimental study point to the existence of a specific antigen in 6 of 13 cases with autosensitization dermatitis and further indicate its close relation to a water-soluble component of bacterial cells of staphylococci. On the basis of clinical observations, microorganisms on a primary lesion, especially staphylococci, may become antigenic in the presence of a severe inflammatory process under certain conditions. Because of absorption of these bacterial substances from a primary lesion, a patient acquires circulating antibodies in her blood stream. These antibodies become attached to remote areas of skin and meet antigenic substances, and an antigen-antibody reaction, dermatitic in nature, results.

This comment, however, on possible mechanisms in autosensitization dermatitis also may not leave from the theoretical category as many previous reports. Because it is distinct that there are many factors involved in the cause of eczema that stay outside the knowledge of present immunology.

\section{CONCLUSIONS}

Data on a study concerning the nature of autosensitization dermatitis are reported here.

1. The 66 cases with autosensitization dermatitis including 34 males and 32 females were examined. The primary lesion was observed on the legs in $52.9 \%$ of these cases, and nummular eczema was most considerable as the primary lesion.

2. The secondary disseminated eruption developed at least 7 days after exacerbation of the primary dermatosis.

3. No significant change was found in 7 cases, who underwent laboratory examinations.

4. The histological changes in secondary disseminated eruption consisted of eczema-like reaction.

5. From the primary lesions with acute exsudative changes, pathogenic staphylococci were predominantly isolated.

6. Both the content of secondary eruption and the venous blood of patient were found to be sterile by culture.

7. Immunologic method showed the presence of antibody to the extract of 
staphylococci in 6 of 13 patients. This abnormal antibody was absent in normal serum.

8. Autosensitization dermatitis is considered to be an allergic reaction. Although the capacity for antigenicity is probably not limited to any one source, staphylococci seem to play some role as one of the sources. The antigenic substance might be a water-soluble fraction of staphylococcal components.

Grateful acknowledgement is made to the late Prof. Dr. Yokoyama, and to Prof. Dr. Hatano, Director of Department of Dermatology. The assistance of Prof. Dr. Ushiba, and of Assistant Prof. Dr. Sasaki, Department of Bacteriology, is also gratefully acknowledged.

\section{REFERENCES}

1. Whitfield, A.: Lancet, ii : 122, 1921.

2. Whitfield, A.: Brit. J. Derm., $34: 331,1922$.

3. Whitfield, A.: Brit. Med. J. 2: 332, 1926.

4. Dennie, C. C. et al.: Arch. Derm. Syph., 20: 698, 1929.

5. Brown, W. H.: Brit. J. Derm., 51: 197, 1939.

6. Hopkins, H. \& Burky, E. L.: Arch. Derm. Syph., 49: 124, 1944.

7. Smith, S. W.: Brit. Med. J., 1: 628, 1945.

8. Hecht, H. et al.: J. Exp. Med., 78: 59, 1943.

9. Templeton, H. et al.: Arch. Derm. Syph., 59: 68, 1949.

10. Cormia, F. E. \& Esplin, B. M.: Arch. Derm. Syph., 61: 931, 1950.

11. Esplin, B. M. \& Cormia, F. E.: Arch. Derm. Syph., 64: 31, 1951.

12. Lipschultz, C. E.: Arch. Derm. Syph., 68: 178, 1953.

13. Haxthausen, H.: Acta derm.-venereol., 35: 271, 1955.

14. Young, A. W. Jr.: Arch. Derm. Syph., 77: 495, 1958.

15. Miescher, G.: Arch. f. Dermat. u. Syph., 188: 36, 1950.

16. Robert, P.: Arch. f. Dermat. u. Syph., 173: 267, 1935.

17. Storck, H.: Dermatologica, $96: 177,1948$.

18. Röckl, H.: Hautarzt, 6: 532, 1955.

19. Röckl, H.: Ibid., 7: 14, 1956.

20. Röckl, H.: Ibid., 7: 70, 1956.

21. Röckl, H.: Ibid., 7: 113, 1956.

22. Röckl, H.: Ibid., 7: 248, 1956.

23. Röckl, H.: Ibid., 7: 304, 1956.

24. Yamazaki, J.: Jap. Med. J., No. 1549: 60, 1954. (in Japanese)

25. Ofuji, S. et al.: Acta Dermatologica, $52: 148,1957$. (in Japanese)

26. Anekoji, K.: Jap. J. Dermat., 68: 818, 1958. (in Japanese)

27. Tanaka, S.: Jap. J. Dermat., $69: 1576,1959$. (in Japanese)

28. Strempel, R.: Arch. f. Dermat. u. Syph. 195: 650, 1953.

29. Monacelli, M.: Hautarzt, 5: 279, 1954.

30. Sulzberger, M. B.: Year Book of Derm. Syph.

31. Wedroff, N. S.: Arch. f. Derm. u. Syph., 171: 641, 1935.

32. Yasuda, T. \& Takano, S.: Hormone and Clinic, 4: 1123, 1956. (in Japanese) 
33. Rayer, P.: A Theoretical and Practical Treatise on Diseases of the Skin, p. 114, 1845.

34. Unna, P. G.: Deutsche Med.-Ztg., 21: 809, 1900.

35. Engman, M. F.: Am. Med., 4: 769, 1902.

36. Lane, C. G. et al.: J.A.M.A., 128: 987, 1945.

37. Fowle, L. P. \& Rice, J. W.: Arch. Derm. Syph., 68: 69, 1953.

38. Wilson, G. S. \& Atkinson, J. D.: Lancet, i: 647, 1945.

39. Ujiie, A. \& Ito, S.: Jap. J. Bact., 12: 455, 1957. (in Japanese)

40. Ujiie, A. \& Ito, S.; Jap. J. Bact., 12: 707, 1957. (in Japanese)

41. Ouchterlony, Ö.: Progress in Allergy, 5: 1, 1958.

42. Katsura, T.: Practical Serology, Igakushoin, Tokyo, p. 40, 1956. (in Japanese)

43. Wilson, M. W. \& Pringle, B. H.: J. Immunol., 73: 232, 1954.

44. Simon, F. A.: J. Allergy, 15: 338, 1944.

45. Simon, F. A.: J.A.M.A., 125: 350, 1944. 


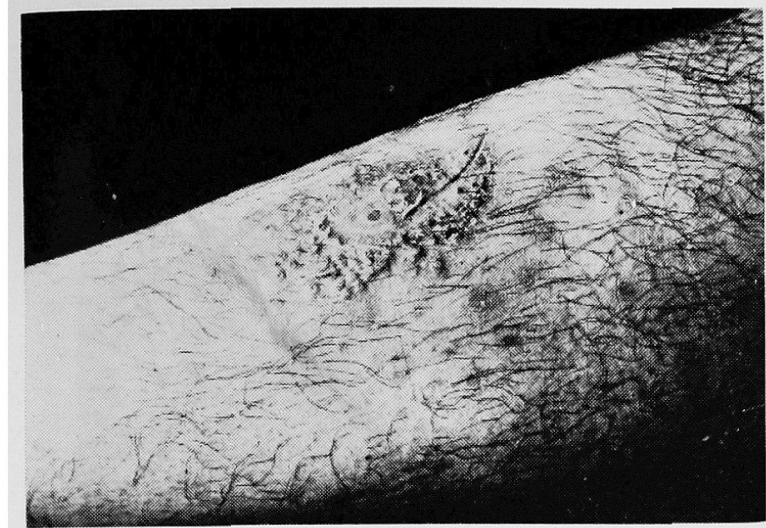

Fig. 1 Primary lesion due to burn on leg.

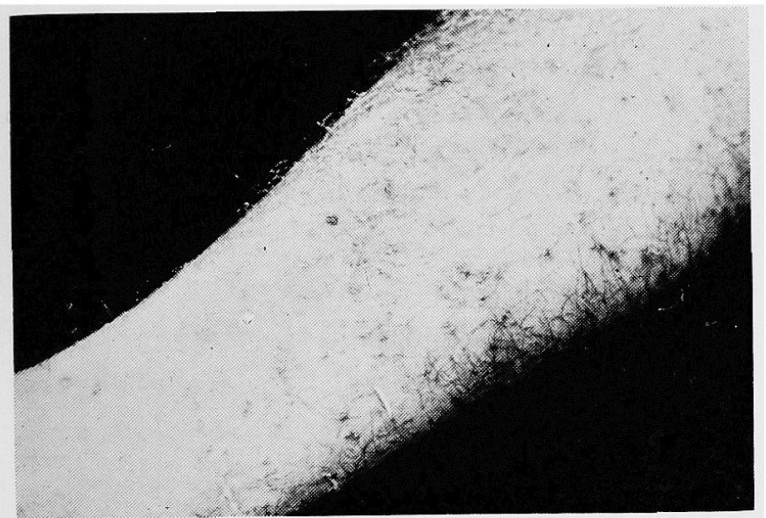

Fig. 2 Early stage. Single vesicles and pustules appearing on intact skin.

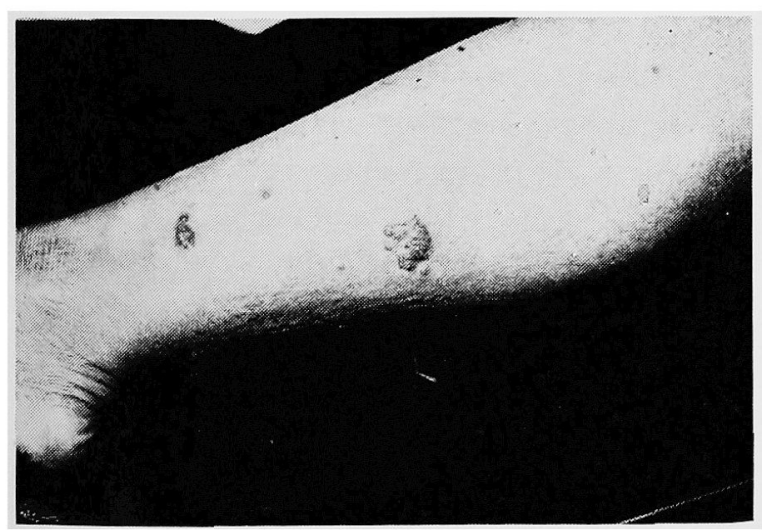

Fig. 3 Single and grouped vesicles tending to form nummular eczema-like lesion.

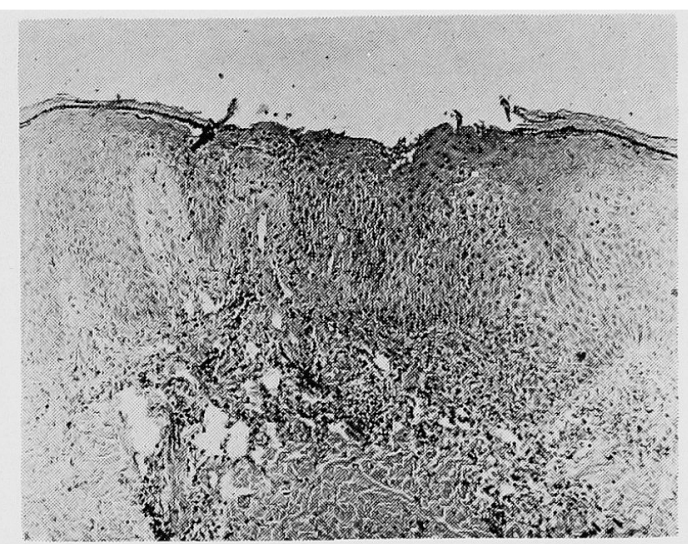

Fig. 4 The epidermis is acanthotic and showes intra- and intercellular edema. There is a considerable perivascular small round cell infiltiation and dilated blood vessels.

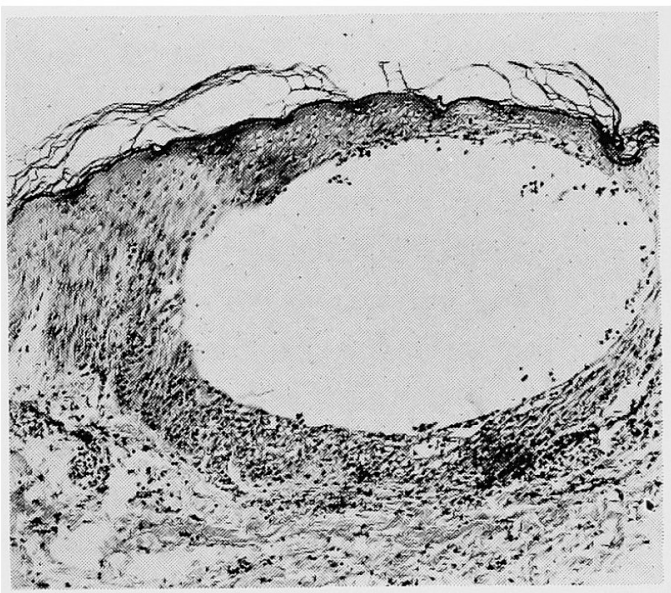

Fig. 5 There is intraepidermal vesicle formation. The dermis shows a perivascular infiltrate.

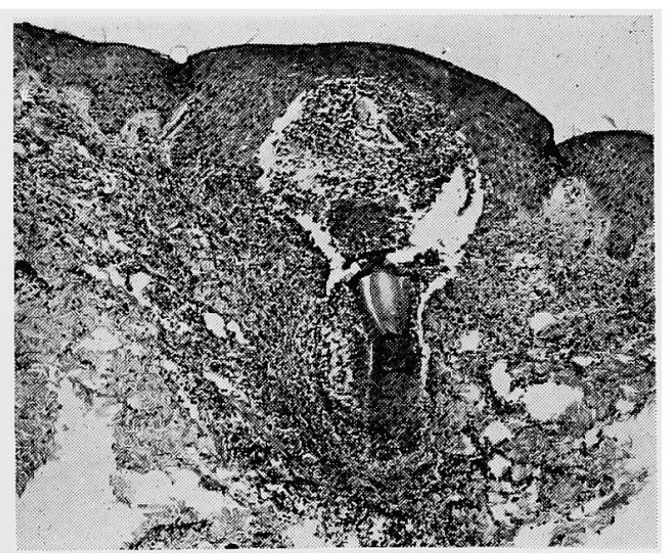

Fig. 6 A perifollicular abscess composed of a dense mass of polymorphonuclear leukocytes with a few lymphocytes. The hair with its follicle and its sebaceous gland is destroyed in the process. 


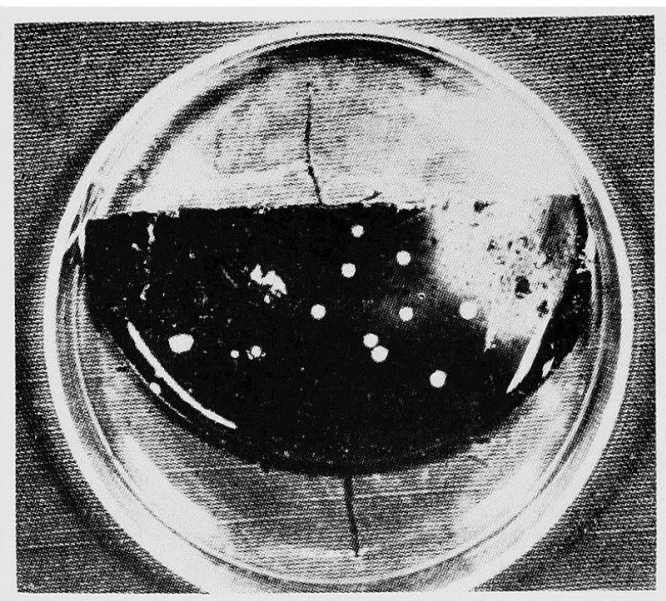

Fig. 7 Culture from normal skin shows only a few colonies.

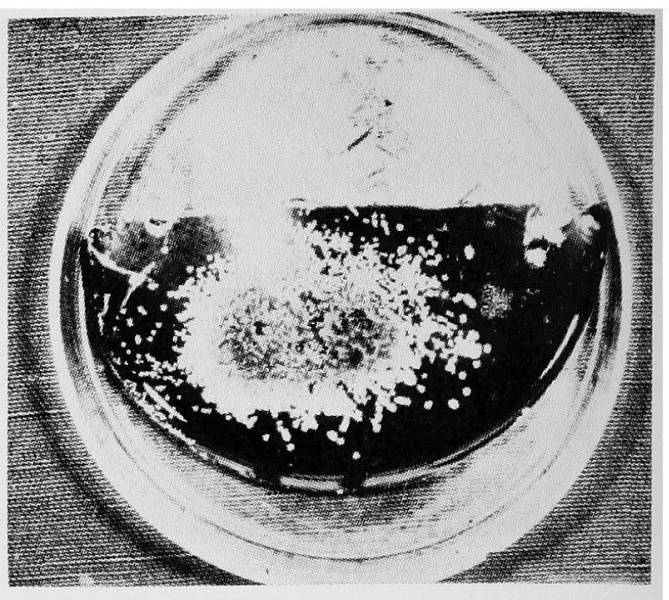

Fig. 8 Numerous colonies are observed on the culture from a primary lesion.

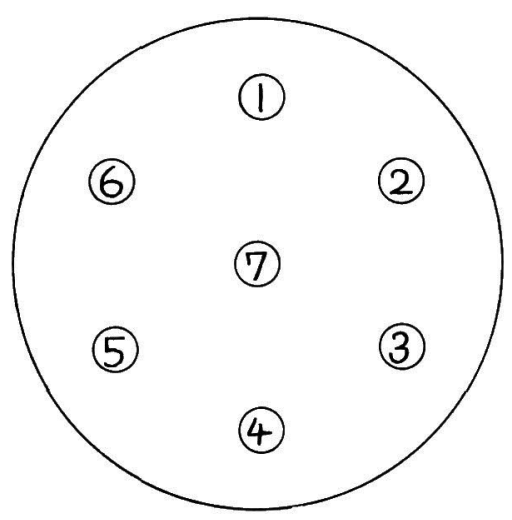

Fig. 9 Pattern used for loading Ouchterlony plates.

1: Scale extract

2: Sterile filtrate of staph. broth culture

3: Extract of staph.

4: Scale extract sensitized by 2

5: Scale extract sensitized by 3

6: Control broth

7: Serum
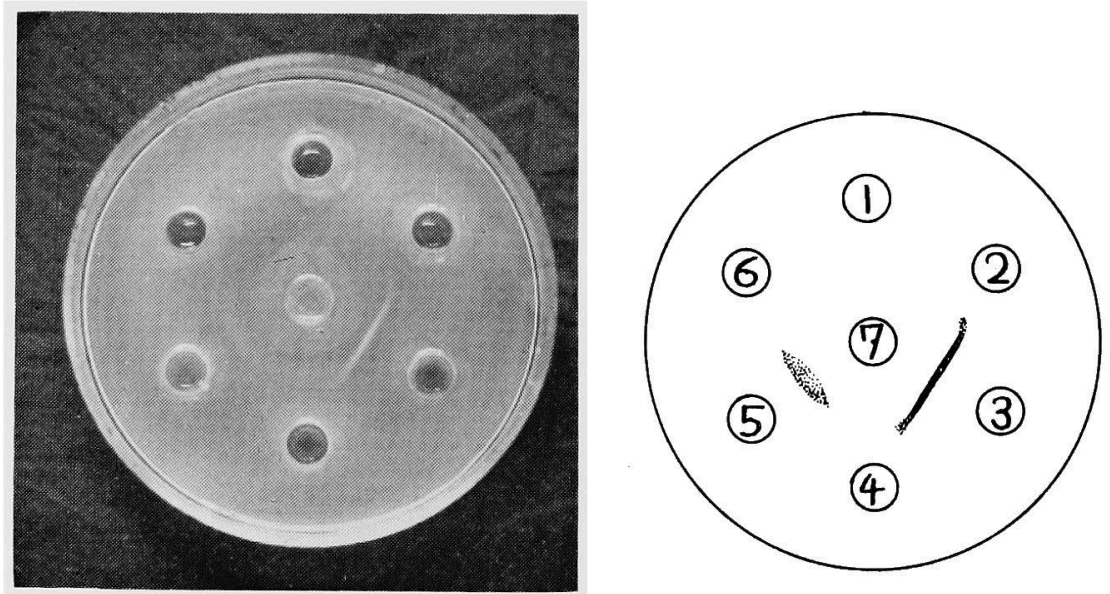

Fig. 10 Patient serum in center hole against six test substances. Note presence of band against extract of staph., and also weak and hazy band against scale extract sensitized by extract of staph. 